\title{
Greenfield investments, cross-border M\&As, and economic growth in emerging countries
}

\author{
Hiep Ngoc Luu* \\ School of Management, University of St Andrews, UK \\ Centre for Applied Economics and Business Research, Hanoi, Vietnam
}

Received: 28 March 2016

Revised: 3 September 2016

Accepted: 5 October 2016

\begin{abstract}
This paper investigates the effect of foreign direct investment (FDI) on economic growth in emerging countries through its two major entry modes: Greenfield investments and cross-border mergers and acquisitions (M\&As). We found that both Greenfields and M\&As contribute positively to accelerating growth. In addition, emerging countries could obtain more benefits from Greenfields and M\&As if the human capital levels were enhanced. We also found that while growth did not have any significant impact on Greenfield investment levels, lower economic growth could lead to higher M\&A flows.
\end{abstract}

Keywords: cross-border M\&As; Greenfields; economic growth; emerging countries.

JEL Classification Codes: F21, O40, C36

\section{Introduction}

Economic research has devoted significant effort to examining the effect of FDI on economic growth. Nevertheless, empirical evidence on whether and how FDI influences growth is still being debated.

Within the neo-classical model, FDI is hypothesised to promote growth through its contribution to capital formation (Solow, 1975). In latter study, Herzer el al. (2008) claim that supplementary capital brought about by FDI under the Solow-type standard framework has no long-term impact on growth. The new endogenous growth model on the other hand emphasised the importance of human capital and technology in the production function of the recipient economies. According to De Mello (1997), FDI might encourage the incorporation of new technologies and knowledge transfer from more developed nations to less developed ones, leading FDI, as a bundle of money capital plus an increase in existing stock of knowledge

\footnotetext{
*E-mail: nhl3@st-andrews.ac.uk.

Citation: Luu, H.N. (2016) Greenfield investments, cross-border M\&As, and economic growth in emerging countries, Economics and Business Letters, 5(3), 87-94.
} 
through human capital spillover and technological diffusion, to have a permanent and positive effect on growth. Nevertheless, a large number of studies have suggested that the positive technological and knowledge spillovers proposed by endogenous growth theories may not exist in less-developed nations. According to Kokko et al. (1996), domestic firms in less-developed countries, using very backward production technologies and a low-skilled labour, may not be able to learn and benefit from multinational enterprises if the technology and knowledge gap is too wide. Aitken and Harrison (1999) eventually found that the increasing existence of foreign enterprises could have negative impacts on the host country's economy. This could be more of a problem if investment inflows into a less-developed country are primarily in the form of resource-seeking FDI - a situation in which foreign investors invest abroad to obtain resources and other input supplies that are either too costly to obtain or unavailable in the home market (Brouthers et al., 2008). According to Nunnenkamp and Spatz (2004), resource-seeking investors are likely to focus on "enclaves dominated by foreign affiliates with few linkages to the local product and labour markets". Under this circumstance, inward FDI might not effectively contribute to host country's economic growth. Thus, if FDI draws away a country's scarce-resources, while labour skill and technological level is not sufficient to absorb advancements and other benefits from FDI, then such investments could discourage the positive spillovers, and eventually, cause some kind of "Dutch Disease" effects. (Nunnenkamp and Spatz, 2004). To this end, there is no unmitigated finding on the FDI-growth nexus. And as Durham (2004) proposed, the impacts of FDI on growth may vary differently, depending upon the absorptive capacities of each nation. Despite this large body of literature, researchers have mostly focused only on the impact of total inward investment and not differentiated FDI by its type and mode of entry, making empirical studies in this tradition surprisingly limited. The purpose of this paper is therefore to close this gap in the literature by examining the effect of FDI on growth through its two major modes: Greenfield investments and cross-border M\&As.

Existing literature on the economic consequences of Greenfields and M\&As has pointed out the possibility that Greenfields would contribute to increasing the recipient's capital formation and productivity, while M\&As may not (Kim, 2009). This is because, whereas Greenfields involve the direct investment and construction of new facilities, cross-border M\&As involves the transfer of the recipient country's income to the home market. As a result, M\&As might not lead to any capital formation and/or productivity enhancement of the host country. Under these circumstances, although some studies (i.e. Blonigen and Slaughter, 2001) suggested that Greenfields do not have much contribution to skill-upgrading - an important driver of growth, according to Calderón et al. (2004), as long as this type of FDI and domestic investments are not substitutes, it should have a positive impact on the host country's economic growth through capital formation via increasing foreign-owned physical capital.

In addition, according to Agosin and Machado (2005), FDI in the form of cross-border M\&As may not actually lead to any increment in the physical capital of a capital-scarce country. Rather, it merely represents the ownership transfer of existing assets from domestic to foreign entities. Thus, if the proceeds from the selling of these assets are spent on consumption and imports, FDI would not directly promote the growth of productive capacities, and therefore economic growth (Mencinger, 2003). From this perspective, cross-border M\&As are more likely to be resource-seeking FDI. Nonetheless, some other studies (see, i.e. Barrell and Pain (1997); and Conyon et al. (2002)) claim the contrary, that cross-border M\&As could actually improve the rate of technical progress and productivity in the recipient country and therefore promote the long-run rate of economic growth.

In short, there is no consensus on theoretical and empirical evidence on the impact of Greenfield investments and cross-border M\&As on economic growth. To the best of our knowledge, we are the first to empirically compare and analyse the impact of Greenfields and 
M\&As on growth in emerging countries. Emerging countries provide an interesting case study because, while foreign multinational enterprises could be attracted to the various opportunities offered in fast-growing markets (Meyer, 2005), they might also be exposed to a number of rules and regulations set by the host country policy-makers (Agosin and Machado, 2005). Such rules and regulations could disfavour FDI, and subsequently discourage growth. This motivates us to expand previous studies (i.e. Agosin and Machado, 2005; Wang and Wong, 2009; and Eren and Zhuang, 2015) by looking at the potential bidirectional relationship between Greenfield/M\&As and growth We found that both Greenfields and M\&As contribute positively to promote economic growth. In addition, while growth did not have any significant impact on Greenfield investment levels, lower economic growth could lead to higher M\&A inflows.

By looking at the impact of FDI on economic growth through its two major modes of entry: Greenfield investments and cross-border M\&As, this study is mostly close to the prior research by Wang and Wong (2009). However, our study is different from Wang and Wong's paper in a number of ways. First, although the two authors have examined a large sample of nations, they did not control for the possible different growth impacts that Greenfields/M\&As might bring to developed, emerging, and least-developed countries, meaning the overall empirical results might be affected by the problem of data comparability. Thus, by looking explicitly only at emerging economies, this paper can largely mitigate the data comparability problem, making the empirical results and its interpretations more reliable. Second, due to the problem or lacking available data, Wang and Wong only use the difference between FDI and M\&As as a proxy for the volume of Greenfields into a host nation. This could lead to an inherit problem of data and measurement bias, which consequently might cause a number of serious econometric issues (see, i.e. Roberts and Whited, 2012). Thus, by collecting Greenfields and M\&As data from two separate datasets from the UNTACD database over the 2003-2014 period, we not only can conduct the most up-to-date study, but also can mitigate the issue of data bias as well as overcome the problem of lacking reliable data claimed by Byun et al. (2012).

Finally, like most other previous studies, Wang and Wong did not explicitly account for the endogeneity problem. Their empirical findings are mainly drawn from the result of the weighted-least-squares model. Although the two authors have checked and utilised the instrumental variable (IV) method to address the explored endogeneity concern, it could not prevent them from exposing to another endogeneity problem driven by, for example, the measurement bias noted earlier. This partly explains why in Wang and Wong's research, only Greenfield is identified as an endogenous variable, whereas in our study, we found both Greenfields and cross-border M\&As are endogenously formed. In this paper, the two-step GMM estimator is used to address the (potential) endogeneity issue of the bidirectional relationship between Greenfields/M\&As and economic growth. According to Vallascas and Hagendorff (2013), as long as the selected instrumental variables are valid, the two-step GMM estimator provides higher levels of estimation consistency and efficiency, compared to other traditional econometric methods like ordinary-least-square and two-stage least square estimators.

With regard to data and sample, our choice of countries is based on the FTSE country classification. Accordingly, our sample includes 12-year data (2003-2014) for these 21 emerging countries: Indonesia, Malaysia, Philippines, Thailand, Brazil, Czech Republic, Hungary, Mexico, Poland, South Africa, Turkey, Chile, China, Columbia, Egypt, India, Pakistan, Peru, Russia, Taiwan, and United Arab Emirates. Of the 21 countries that were originally included in the FTSE list, we excluded Taiwan due to the lack of data available, reducing our countries of study to 20 . 


\section{Data and model specification}

We investigate the bidirectional relationship between FDI and growth using a dynamic panel two-step GMM estimator. As suggested by Vallascas and Hagendorff (2013), this method is appropriate for the problems of unobservable heterogeneity and simultaneity, and also the dynamic endogeneity issue.

Based on the existing literature (i.e. Anwar and Nguyen, 2010), FDI and growth could be influenced by other factors. Thus, we incorporate jointly in the Growth equation: Population (using population growth), Export (using export-to-GDP ratio), Expenditure (using government expenditure-to-GDP ratio), Inflation, Exchange (using real-exchange rate), Human (human capital, using gross primary enrollment-to-population ratio), Technology (to measure technology gap = US. GDP-per-capita - host country GDP-per-capita), Geography (using coastline-to-area ratio), and Agriculture (using agriculture-value-added-to-GDP ratio). In addition we also examine whether FDI affect growth via absorptive capacity of the host countries by incorporating the interaction terms FDI*Human and FDI*Technology into the Growth equations.

In the FDI equation, we add Size (market size, using real GDP), Openness (trade openness, using (Import+Export)/GDP ratio), Infrast_1 and Infrast_2 (infrastructure variables, using mobile cellular subscription rate and internet users-per-100-people, respectively), Unemployment (using unemployment rate), Inflation, and Exchange as other determinants of FDI. Our data is collected from either the World Bank ${ }^{1}$ or $\mathrm{IMF}^{2}$ databases.

Thus, our model is specified as followed:

$$
\begin{aligned}
\text { Growt }_{i t} & =\delta_{0}+\delta_{1} \text { Growth }_{i, t-1}+\delta_{2} \text { FDI }_{i t}+\delta_{3} \text { Population }_{i t}+\delta_{4} \text { Export }_{i t} \\
& +\delta_{5} \text { Human }_{i t}+\delta_{6} \text { Technology }_{i t}+\delta_{7} \text { Expenditure }_{i t} \\
& +\delta_{8} \text { Georaphy }_{i t}+\delta_{9} \text { Agriculture }_{i t}+\delta_{10} \text { Inflation }_{i t} \\
& +\delta_{11} \text { Exchange }_{i t}+\delta_{12}\left(F D I_{i t} * \text { Human }_{i t}\right) \\
& \left.+\delta_{13} \text { FDI }_{i t} * \text { Technology }_{i t}\right)+\mu_{t} \\
\text { FDI }_{i t} & =\gamma_{0}+\gamma_{1} \text { FDI }_{i, t-1}+\gamma_{2} \text { Growth }_{i t}+\gamma_{3} \text { Size }_{i t}+\gamma_{4} \text { Openness }_{i t} \\
& +\gamma_{5} \text { Infrast_ }_{i t}+\gamma_{6} \text { Infrast_ }_{i t}+\gamma_{7} \text { Unemployment }_{i t} \\
& ++\gamma_{8} \text { Inflation }_{i t}+\gamma_{9} \text { Exchange }_{i t}+\varepsilon_{t}
\end{aligned}
$$

Where: Growth $h_{i t}$ is annual GDP growth rate in country $i$ at time $t$; FDI takes value of either Greenfield or M\&A; Greenfield is the value of Greenfield projects as share of GDP; and M\&A is the value of cross-border M\&As sales as share of GDP.

Theoretically, the problem of endogeneity could be avoided if appropriate instruments are utilised. Nevertheless, a practical problem is that finding a good instrumental variable is particularly challenging since an appropriate instrument should be highly correlated with the endogenous variable but not with the error-term (Wooldridge, 2008). Following Cole et al. (2006), this study employs infrastructure development variables (Infrast_1 and Infrast_2) as instruments for FDI in the Growth equation because mobile cellular subscription and internet user rates are less likely to be correlated with the disturbance term while they are expected to be highly correlated with FDI inflows in the way that a well-developed infrastructure system could help to facilitate the distribution of output, reduce transaction costs and subsequently, increase productivity for investors. Meanwhile, log of land size and length of coastline are selected as instruments in the FDI equations since according to Presbitero (2006), geography is

\footnotetext{
${ }^{1}$ ULR: http://data.worldbank.org/

${ }^{2}$ ULR: http://data.imf.org/?sk=7CB6619C-CF87-48DC-9443-2973E161ABEB
} 
one of the key determinants of economic growth, and due to its exogenous nature, land size and coastline should have no correlation with the error-term.

\section{Empirical results}

The results of our model are reported in Tables 1 and $2^{3}$. Columns 1.1 and 1.2 of Table 1 present estimates for the impacts of Greenfields and M\&As on growth, respectively. As can be seen from regression 1.1, Greenfields can directly and positively contribute to accelerated economic growth since the estimated coefficient on Greenfields is positive and statistically significant. This finding is in line with what has traditionally been proposed due to the expectation that Greenfields would increase capital formation, and therefore economic growth, via increasing foreign-owned physical capital through direct investment and construction of new facilities in the host country.

A similar impact is observed in the case of M\&As. While the positive effect of Greenfields on growth is traditionally expected (Agosin and Machado, 2005), the positive M\&As-growth nexus provided a somewhat interesting result different from that found by Wang and Wong (2009). This is perhaps because M\&As could also provide the recipient country with additional external financial resources as do Greenfield (Ashraf et al., 2015). And thus, if the newlyacquired firms invest in opportunities in new sectors of a fast-growing economy, this could lead to capital formation (Agosin and Machado, 2005).

Table 1. Impact of Greenfields and M\&As on Growth.

\begin{tabular}{lcc}
\hline \hline Growth (1.1) & Growth $(1.1)$ & Growth $(1.2)$ \\
\hline Greenfields & $10.48194(0.039)$ & \\
M\&As & & $9.678472(0.051)$ \\
Growth ${ }_{\text {- } 1}$ & $0.223347(0.045)$ & $0.228377(0.057)$ \\
Population Growth & $-0.561137(0.115)$ & $-0.285818(0.365)$ \\
Export & $-0.013774(0.417)$ & $-0.006520(0.666)$ \\
Human & $0.309946(0.004)$ & $0.304149(0.004)$ \\
Technology & $-0.000123(0.350)$ & $0.000054(0.741)$ \\
Expenditure & $-0.131895(0.000)$ & $-0.1459141(0.000)$ \\
Geographic & $-4.844537(0.530)$ & $-3.685028(0.651)$ \\
Agriculture & $0.175462(0.007)$ & $0.072290(0.277)$ \\
Inflation & $0.08844(0.118)$ & $0.123417(0.040)$ \\
Exchange & $-0.000209(0.005)$ & $-0.000182(0.010)$ \\
Greenfield*Human & $-9.466911(0.055)$ & \\
M\&A*Human & & $-6.772255(0.052)$ \\
Greenfield*Technology & $-0.001178(0.651)$ & \\
M\&A*Technology & & $-0.005687(0.224)$ \\
Constant & $-21.24904(0.057)$ & $-27.9594(0.066)$ \\
Hausman Specification Test $(P$-value) & 0.0828 & 0.0727 \\
Underidentification Test $(P-$ value) & 0.0007 & 0.0076 \\
Hansen J-statistic (P-value) & 0.3256 & 0.7449 \\
No. Obs. & 158 & 158 \\
\hline \hline
\end{tabular}

Note: p-values are in parentheses.

\footnotetext{
${ }^{3}$ Initially, the Hausman specification tests were utilised to test for endogeneity and since the p-values are all statistically significant, endogeneity is a problem and two-step GMM will offer more consistent results than those reported by OLS. Also, the null hypotheses of Hansen J-tests for over-identification restriction cannot be rejected, while under-identification tests are all statistically significant, indicating that our selected instruments are valid.
} 
Testing for the indirect impacts of Greenfields and M\&As on growth, we found that as far as the level of human capital is concerned, emerging countries have not reached the required minimum human capital threshold. Meanwhile, the estimated coefficients on Greenfields*Technology and $M \& A *$ Technology are both negative and not statistically significant.

Table 2 reveals several interesting results for the influences of growth on Greenfields and M\&As. Higher economic growth appears to promote additional Greenfield inflows. However, the evidence is weak since the estimated coefficient on Growth is not statistically significant. Meanwhile, regression 2.2 indicates that lower economic growth does lead to greater crossborder M\&A flows. This finding is consistent with the claims of Byun et al. (2012) that in financial difficult times, targeted companies became dramatically cheaper due to a sharp depreciation in the exchange rate and significant deterioration in firm values.

Table 2. Impact of Growth on Greenfields and M\&As.

\begin{tabular}{lcc}
\hline \hline & Greenfields $(2.1)$ & $M \& A s(2.2)$ \\
\hline \hline Growth & $0.120406(0.136)$ & $-0.064038(0.059)$ \\
M\&Ast 1 & $0.280211(0.004)$ \\
Greenfieldt-1 & $0.429857(0.000)$ & \\
Size & $0.000003(0.000)$ & $0.000002(0.012)$ \\
Openness & $-0.000262(0.924)$ & $0.009743(0.017)$ \\
Unemployment & $-0.029603(0.169)$ & $-0.032011(0.218)$ \\
Inflation & $-0.019861(0.405)$ & $0.020071(0.545)$ \\
Exchange & $0.000014(0.622)$ & $-0.000016(0.704)$ \\
Mobile Cellular Subscription & $-0.000778(0.861)$ & $-0.017351(0.049)$ \\
Internet User & $0.013537(0.101)$ & $0.0002719(0.977)$ \\
Constant & $1.227211(0.036)$ & $0.000271(0.007)$ \\
Hausman Specification Test $(P$-value) & 0.0000 & 0.0000 \\
Underidentification Test $(P$-value) & 0.0000 & 0.0000 \\
Hansen J-statistic $(P$-value) & 0.6221 & 0.6262 \\
No. Obs. & 220 & 220 \\
\hline \hline
\end{tabular}

Note: p-values are in parentheses.

\section{Conclusion remark}

Using UNCTAD data, we present new empirical evidence on the impact of FDI in the form of Greenfield investment and cross-border M\&As on emerging countries' economic growth over the 2003-2014 period. We found that Greenfields and M\&As do have a positive homogenous effect on growth. Additionally, the enhancement of human capital is an important prerequisite for the host countries to derive the most benefits from Greenfields and M\&As. Also, there is empirical evidence of a two-way linkage between FDI and growth. However, the bidirectional relationship exists only for the M\&As-growth nexus.

\section{References}

Agosin, M. and Machado, D. (2005) Foreign Investment in Developing Countries: Does it Crowd in Domestic Investment?, Oxford Development Studies, 33(2), 149-162.

Aitken, B.J. and Harrison, A.E. (1999) Do domestic firms benefit from direct foreign investment? Evidence from Venezuela, American Economic Review, 605-618.

Anwar, S. and Nguyen, P.L. (2010) Foreign direct investment and economic growth in Vietnam, Asia Pacific Business Review, 16(1-2), 183-202. 
Ashraf, A. Herzer, D. and Nunnenkamp, P. (2015) The Effects of Greenfield FDI and Crossborder M\&As on Total Factor Productivity, The World Economy, 2015.

Barrell, R. and Pain, N. (1997) Foreign Direct Investment, Technological Change, and Economic Growth Within Europe, The Economic Journal, 107(445), 1770-1786.

Blonigen, B. and Slaughter, M. (2001) Foreign-Affiliate Activity and U,S, Skill Upgrading, Review of Economics and Statistics, 83, 362-376.

Byun, H.S., Lee, H.H. and Park, C.Y. (2012) Assessing Factors Affecting M\&As versus Greenfield FDI in Emerging Countries, ADB Economics Working Paper.

Brouthers, L.E., Gao, Y. and McNicol, J.P. (2008) Corruption and market attractiveness influences on different types of FDI, Strategic Management Journal, 29(6), 673-680.

Calderón, C. Loayza, N. and Servén, L. (2004) Greenfield Foreign Direct Investment and Mergers and Acquisitions: Feedback and Macroeconomic Effects, World Bank Working Paper, WPS3192.

Cole, M.A. Elliott, R.J.R. and Fredriksson, P. G. (2006) Endogenous Pollution Havens: Does FDI Influence Environmental Regulations?, Scandinavian Journal of Economics, 108(1), 157-178.

Conyon, M. Girma, S. Thompson, S. and Wright, P. (2002) The Productivity and Wage Effect of Foreign Acquisition in the United Kingdom, Journal of Industrial Economics, 50, 85102.

De Mello, L.R. (1999) Foreign direct investment-led growth: evidence from time series and panel data, Oxford Economic Papers, 51(1), 133-151.

Durham, J.B. (2004) Absorptive capacity and the effects of foreign direct investment and equity foreign portfolio investment on economic growth, European Economic Review, 48(2), 285-306.

Eren, M. and Zhuang, H. (2015) Mergers and Acquisitions Versus Greenfield Investment, Absorptive Capacity, and Economic Growth: Evidence from 12 New Member States of the European Union, Eastern European Economics, 53, 99-123.

Fenny, S., Iamsiraroj, S. and McGillivray, M. (2014) Growth and Foreign Direct Investment in the Pacific Island countries, Economic Modelling, 37(2014), 332-339.

Kim, Y.H. (2009) Cross-border M\&A vs, greenfield FDI: Economic integration and its welfare impact, Journal of Policy Modeling, 31(2009), 87-101,

Kokko, A., Tansini, R. and Zejan, M.C. (1996) Local technological capability and productivity spillovers from FDI in the Uruguayan manufacturing sector, The Journal of Development Studies, 32(4), 602-611.

Mencinger, J. (2003) Does Foreign Direct Investment Always Enhance Economic Growth?, Kyklos, 56, 491-508.

Meyer, K.E. (2005) Foreign Direct Investment in Emerging Economies, Policy Discussion Paper.

Nunnenkamp, P. and Spatz, J. (2004) Transitional Corporations, 13(3), 52-86.

Presbitero, A. (2006) Institutions and geography as sources of economic development, Journal of international development, 18 (3), 351-378.

Roberts, M.R. and Whited, T.M., 2012. Endogeneity in Empirical Corporate Finance, Simon School Working Paper, FR11-29.

Solow, R.M. (1957) Technical Change and the Aggregate Production Function, The Review of Economics and Statistics, 39(3), 312-320.

Vallascas, F. and Hagendorff, J., 2013. CEO Remuneration and Bank Default Risk: Evidence from the U,S, and Europe, Review of Finance, 22(2), 47-89.

Wang, M. and Wong, S. (2009) What Drives Economic Growth? The Case of Cross-Border M\&A and Greenfield FDI Activities, Kyklos, 62(2), 316-330. 
Wooldridge, J.M. (2008) Introductory Econometrics: A Modern Approach, 4th ed, Ohio: Cengage Learning. 